\title{
N. Teliura
}

\author{
O.M. Beketov National University of Urban Economy in Kharkiv, Ukraine
}

\section{CURRENT ISSUES OF TECHNOLOGICAL AND ORGANIZATION-ECONOMIC TOOLS OF NATURE MANAGEMENT, ENVIRONMENTAL ASSESSMENT AND ENTREPRENEURSHIP}

\begin{abstract}
Significant technological advances are being made across a range of fields, including technological and organization-economic tools, particularly in terms of nature management, environmental assessment and entrepreneurship to name but a few. The Green entrepreneurship as alternative vision for growth and development. These breakthroughs are expected to be highly disruptive and bring about major transformative shifts in how societies function. These advances promise significant social and economic benefits, increased efficiency, and enhanced productivity across a host of sectors. These innovations including technological and organization-economic tools are centered on the gathering, processing, and analyzing of enormous reams of data emerging from the information sciences with implications for countless areas of research and development.
\end{abstract}

Keywords: technological and organization-economic tools, soil cover, management of projects and programs, environmental assessment and entrepreneurship.

\section{Statement of the problem}

Technologies and organization-economic tools as become important with the possibility of their further use, which will cause multiple and serious problems, it can affect both migratory labor flows, including redeployment of labor, other transformational market changes, the emergence of exacerbation of existing inequalities and new risks to environmental and national security. Technologies and organizational and economic tools in various spheres of our social life have a dual use and can be applied, as much as they need to strengthen and expand socio-ecological and economic development, which leads to increased efforts to manage them much more complex. Most of them are relatively easy to access and use, but they are inherently more vulnerable to operation, which can lead to deviations both today and in the future.

Most countries increasingly view Green entrepreneurship technologies and organization-economic tools as central to national security. But given the increasing and deepening of economic integration and interconnectedness, it must be borne in mind that the global and techno-economic implications are much less localized than before and may extend to countries and industries around the world.

The signing the As.-Ag. between Ukraine, on the one hand, and the EU and its countries, other hand, opens new opportunities and creates new standards in various spheres of public life, including the field of environmental protection.

Resolutions of international summits on sustainable development have identified the need to move to the principles of sustainable environmental, socio-economic development of most countries. Based on the recommenddations of international summits, the strategic goal of Ukraine's further development is to transform its natural resource potential into a basis for economic growth, which corresponds to the understanding of the foundations of sustainable development from the standpoint of the whole world.

Ensuring the way out of the crisis, including the development of settlements. The problem of preservation, restoration and economical use of soil and other natural resources today is one of the most important environmental problems. Soil science today plays a leading role in the development of leading technologies and approaches to economical use and especially the restoration of productive lands. Development of recommendations on the monitoring system and regulatory framework for the use of highly productive land is a priority.

The development and substantiation of ways of gradual implementation of European standards and norms aimed at ensuring including technological and organization-economic tools the environmental safety in settlements deserves special attention.

\section{Analysis of recent researches and publications}

Complex, dynamic technologies and organizationeconomic tools already govern fields of nature management, environmental assessment and green entrepreneurship. For instance, fields of nature management, environmental assessment is regulated by norms and provisions of international law; technical 
standards and protocols; standards and norms of trade, business and human rights; research principles; national norms; and self-regulation in the private sector. These legal doctrines are supported by existing norms, values and principles. They cover a variety of environmental areas and issues, and are complemented by a growing set of confidence- and capacity-building measures and efforts to increase security and resilience. However, important elements of this regime remain controversial, even as new risks and vulnerabilities and other technologies emerge and still need to be managed.

Klaus Schwab in [1] the founder of the World Economic Forum (WEF), described technological progress (for better or worse) as a "revolution" because of their "speed, scale and impact of the system" [1]. Schwab K., discussing what he dubbed the "industrial revolution" and giving it number four (4.0:), highlighted a number of new political and regulatory issues. Similarly, the 2019 document [2] prepared for the WEF emphasizes the need to "transform traditional governance structures and policy-making models" and adapt more "flexible" governance methods [2].

Legislators, regulators, private green business leaders, researchers and civil society actors need to be prepared to respond more responsibly and effectively to the consequences and consequences of technological progress and the potential environmental risks they pose. The introduction of new rules, principles and protocols to address specific pressing issues is certainly noteworthy. However, implementing these responses on a large scale and applying them to many cross-border socio-economic and security challenges will be a difficult challenge. This task is likely to require a combination of approaches, increased spending on independent gove-research and the involvement of many private entities other than public Distinguish between domestic and international responsibilities in order to implement sustainable development that requires cross-border coordination and cooperation [11].

Sustainable development is the idea that human societies must live their needs without compromising the ability of future generations to meet their own needs, "official" definition of sustainable development was developed for the first time in the Brundtland Report in 1987 [3].

Specifically, sustainable development is a way of organizing society so that it can exist in the long term. This means taking into account both the imperatives present and those of the future, such as the preservation of the environment and natural resources or social and economic equity.

Goal 11: Sustainable cities and communities. More than half of us live in mega-cities. By 2050, 2/3 of all humanity -6.5 billion people - will be urban. Sustainable development cannot be achieved without significantly transforming the way we build and manage our urban spaces [3].

The rapid growth of cities - a result of rising populations and increasing migration - has led to a boom in mega-cities, especially in the developing world, and slums are becoming a more significant feature of urban life.

Making cities sustainable means creating career and business opportunities, safe and affordable housing, and building resilient societies and economies. It involves investment in public transport, creating green public spaces, and improving urban planning and management in participatory and inclusive ways.

In Ukraine, the priorities of the state environmental policy, defined in the Constitution of Ukraine, and give citizens the right "to a safe environment for life and health" and "ensuring environmental safety and maintaining ecological balance in the country", and are mandatory [4].

It is also necessary to develop new approaches and apply statistical analysis methods to policy and regulation. Advances in environmental management, environmental assessment and eco-entrepreneurship, biotechnology and the convergence of these technologies already provoke multifaceted discussions on the focus and rationale for policies and the most appropriate type of regulation (preventive, preventive, reactive or a combination of all three). Questions arise as to whether to choose tight regulation or soft policy initiatives, such as guidelines, certification procedures and labeling schemes, that do not and do not require mandatory regulations or the current trend of self-government measures by private entities. However, the key question is how to ensure that these regulatory decisions are consistent with their purpose and whether they should be coordinated at the national or international levels [11].

Given the cross-border effects of existing technologies, as well as the growing overlap between them, inconsistent national rules and policies are likely to be ineffective [11].

Finally, new policy and regulatory approaches, including technological and organizational-economic tools, require greater investment in transparency, oversight and accountability mechanisms. This necessitates agreement on the nature and content of national regulatory supervisors. The task should also be to ensure green entrepreneurship and will require organizations to adopt and implement more vigilant controls. For example, green companies should strengthen internal monitoring and external reporting on their self-regulatory initiatives, ensure adequate isolation, publicly fund researchers with secure access to their data, and, above all, ensure that accountability covers all aspects of the supply chain. and these are both direct and indirect costs, such as labor and environmental costs. Such controls could also help identify gaps and engage more participants to help determine whether and 
how a particular technology or application should be regulated [11].

Compliance with environmental safety standards, which are among the most important indicators for assessing the level of development of the state and the implementation of sustainable development strategy requires awareness of it as an extremely important component of environmental policy at the state and regional levels.

Addressing climate and environmental challenges, clearly requires natural scientific knowledge as well as engineering expertise concerning the various technical solutions that can be adopted to mitigate the negative impacts. However, pursuing sustainable technological change is also a societal, organizational, political, and economic endeavor that involves several non-technical challenges [11].

An important problem in implementing the concept of sustainable development and EU requirements at the human level, in the face of environmental degradation, the scale of which has led to loss of resilience of aquatic ecosystems, is the development and justification of ways to reduce the negative impact of water, especially eutrophied water bodies, on human health [5]. The solution of problems of complex assessment and management of ecological safety of settlements located on eutrophied water bodies is done by applying methods of system analysis, on the basis of program-analytical procedures using the method of hierarchy analysis (MHA) [5-7], which will increase the level of validity technological decisions made.

The aim - increasing of an ecological safety of eutrophic water bodies (EWB) of Ukraine via justified choice for implementation priority technologies of ecological safe water disposal in cities, towns and communities.

There are studies that confirm that in cities, towns and communities of Ukraine there is a high level of environmental hazards of EWB - a source of drinking and recreational use.

\section{The main material}

The peculiarities of the implementation of world experience in the implementation of environmentally friendly drainage technologies is impossible without the gradual transformation of drainage systems of a particular city, town and community in an environmentally friendly. This path is determined by the choice of priority technologies for drainage, thereby making a management decision, analyzing socio-ecological and economic indicators and taking into account the natural and climatic characteristics of the study area.

The defined sequence of actions and decisions is the basis of a multi-criteria multi-level hierarchy of choice of drainage technologies, which allows environmentally sustainable operation of the water body as an element of the environment and a source of drinking and recreational use. Program-analytical method of selection and management decision-making on the implementation of technologies and organizational and economic tools, attracts information resources on the modes of nature management, requires the results of environmental assessment and enables the development and implementation of eco-technologies. The introduction of eco-technologies gives impetus to small and medium enterprises for further development, thus implementing the state strategy for a "green" economy.

The author [5, 9, 10] in accordance with [7], developed three stages: Stage I. Construction of a hierarchical model for comparing the elements (features) of the problem. Stage II. Formation of matrices of pairwise comparisons of elements of each level of hierarchy and definition of their local weights. Stage III. Determination of weights, consistency index and selection of the best / priority implementation option [5, $9,10]$.

The developed methodological approach allowed specialists of local authorities in the professional field (environmental, social and economic-technological) to participate in the preparation of a consolidated recommendation for management decisions on the choice of environmentally safe measures in specific cities, towns and communities.

The advantage of the proposed multi-criteria methodological approach is the ability to integrate the decision-making algorithm of the original data, which differ both in their professional content and in the form of presentation (statistical, forecast, direct measurement data, expert assessments).

It is advisable to develop this study in the following areas:

- to increase the stability and consistency of the methodological approach, the development of numerical multicriteria selection hierarchies based on methods of systems analysis (MAS);

- development of recommendations for adaptation of the obtained set of tools during the substantiation of the decision and testing in specific cities, settlements and communities [9, 10].

The transition to a green economy, including technological change, affects the whole of society. It is therefore necessary to not only optimize the performance of the new technologies and identify efficient policies.

\section{Conclusions}

A methodological approach of MAI and MAS to identify priority technologies has been developed. We proposed and used criteria, technologies and organizational and economic tools that were listed as components of sustainable development - environmental, social and economic-technological for the method of decision-making in cities, towns and 
communities.

The elements of the hierarchy were determined on the basis of the management strategy in the system of ecological and national security in the territories of cities, settlements and communities.

The use of the proposed method makes it possible to algorithmize and adjust the procedure for the expert to assess the heterogeneous factors and improve the quality of the results in shaping the decision-making process. In this study, the author suggested an approach to the integrated approach to the management of land and other natural resources for improving the conditions. In this study, the author proposed an approach to an integrated approach to the management of cities, towns and communities, natural resources to improve the living conditions of residents.

The discussions in this article also suggest that green innovation in the public sector should be devoted more attention in future research. Implementing environmental regulations that are close to damages demand specific monitoring technologies that can measure pollution levels.

Such methods multi-criteria multi-level hierarchy of the choice could be particularly relevant for understanding possible future pathways for the greening of key industries.

\section{Література}

1. Klaus Schwab is Founder and Executive Chairman of the World Economic Forum, "The Fourth Industrial Revolution: What It Means, How to Respond» [Електронний ресурс] / World Economic Forum. - Режим доступy : https://www.weforum.org/agenda/2016/01/the-fourth-

industrial-revolution-what-it-means-and-how-to-respond/ 14.01.2016 p. - Загол. з екрану.

2. World Economic Forum, "Agile Governance: Reimagining Policy Making in the Fourth Industrial Revolution,» January 2018 [Електронний ресурс] / World Economic Forum. Режим docmyny : http://www3.weforum.org/ docs/WEF_Agile_Governance_Reimagining_Policy-

making_4IR_report.pdf/-2018 p. - Загол. з екрану.

3. Sustainable Development - What Is It? Definition, History, Evolution, Importance And Examples [Електронний ресурс] / World Economic Forum. - Режим достуny : https://youmatter.world/en/definition/definitions-sustainabledevelopment-

sustainability/\#: : text=Sustainable\%20development $\% 20$ is $\% 2$ Othe\%20idea, the\%20Brundtland\%20Report\%20in\%201987/ 26.05.2020 p. - Загол. з екрану.

4. Конституція України: Закон від 28.06.1996 № 254/к/96BP [Електронний ресурс]. - Режим доступу. http://zakon2.rada.gov.ua/laws/show/254\%D0\%BA/96$\% D 0 \% B 2 \% D 1 \% 80$

5. Teliura N.O. Development of the methodological approach to the selection of technologies for environmentally-safe water drainage in populated areas / N.O. Teliura // Eastern-European Journal of Enterprise Technologies. - 2018. - Vol. 6, No. 10 (96). - P. 55-63. DOI: https://doi.org/10.15587/1729$\underline{4061.2018 .148689}$
6. Дмитриева Е.А. Модель соответствия законодательной базы Украины и Директив ЕС в области биоразнообразия / Е.А. Дмитриева, В.В. Браткевич, Н.А. Телюра // Комунальне господарство міст. Сер. : Технічні науки та архітектура. - 2016. - Bun. 132. - С. 8087.

7. Саати Т.Л. Принятие решений: Метод анализа иерархий: пер. с англ. / Т.Л. Саати ; Переводчик Р.Г. Вачнадзе. M. : Радио и связь, 1993 . - 314 c.

8. Dmitrieva O. Choosing the phytoremediation technologies for cleaning various types of wastewater / O. Dmitrieva, I. Khorenzaiya, V. Vasilyenko, N. Teliuta, O. Lomakina, L. Melnik, I. Koldoba // Eastern-European Journal of Enterprise Technologies. - 2020. - Vol. 2, no. 10. - P. 27-37. DOI: https://doi.org/10.15587/1729-4061.2020.200591

9. Teliura N.O. Ensuring of an ecological safety of eutrophic water bodies via the implementation of priority water disposal technologies in settlements / N.O. Teliura // Wissenschaft für den modernen Menschen: innovative technik und technologie, informatik sicherheitssysteme, verkehrsentwicklung, architektur: monografische reihe "Europäische Wissenschaft». - Karlsruhe. Germany: ScientificWorld-NetAkhatAV, 2021. Buch 4. - Teil 4. - P. 10-19.

10. Телюра Н.О. Підвищення екологічної безпеки евтрофованих водних об'єктів шляхом впровадження пріоритетних технологій водовідведення в населених пунктах : дис. ... канд. техн. наук : 21.06 .01 / Н.О. Телюра. Харків, 2019. $-190 c$.

11. Camino Kavanagh. New Tech, New Threats, and New Governance Challenges: An Opportunity to Craft / Carnegie Endowment for International Peace. - Режим достуny : https://carnegieendowment.org/files/WP_Camino_Kavanagh_ New Tech New Threats.pdf-2019 p. - Загол. з екрану.

\section{Reference}

1. Klaus Schwab is Founder and Executive Chairman of the World Economic Forum, "The Fourth Industrial Revolution: What It Means, How to Respond" / World Economic Forum. https://www.weforum.org/agenda/2016/01/the-fourthindustrial-revolution-what-it-means-and-how-to-respond/ (2016).

2. World Economic Forum, “Agile Governance: Reimagining Policy Making in the Fourth Industrial Revolution" / World Economic Forum. http://www3.weforum.org/docs/WEF_ Agile_Governance_Reimagining_Policy-

making_4IR_report.pdf/ (2018).

3. Sustainable Development - What Is It? Definition, History, Evolution, Importance And Examples / World Economic Forum. https://youmatter.world/en/definition/definitionssustainable-developmentsustainability/\#: :text=Sustainable $\%$ 20development $\% 20$ is $\% 20$ the $\% 20$ idea,the $\% 20$ Brundtland $\% 20$ Report\%20in\%201987/ (2020).

4. The Constitution of Ukraine: Law from 28.06.1996 № 254/K/96-VR. http://zakon2.rada.gov.ua/laws/show/254\% D0\%BA/96-\%D0\%B2\%D1\%80 (1996) [in Ukrainian].

5. Teliura, N.O.: Development of the methodological approach to the selection of technologies for environmentally-safe water drainage in populated areas. Eastern-European Journal of Enterprise Technologies, Vol. 6, No. 10 (96), 55-63 (2018). DOI: https://doi.org/10.15587/1729-4061.2018.148689

6. Dmitrieva, O.O., Bratkevich, V.V., Teliura N.O.: Model of Conformity Regulatory Framework of Ukraine and EU 
Directives Biodiversity. Municipal economy of cities, 132, 80 87 (2016) [in Russian].

7. Saaty, T.L. How to make a decision: The analytic hierarchy process. Radio and Communication, Moscow (1993) [in Russian].

8. Dmitrieva, O., Khorenzaiya, I., Vasilyenko, V., Teliura, N., Lomakina, O., Melnik, L., Koldoba, I.: Choosing the phytoremediation technologies for cleaning various types of wastewater. Eastern-European Journal of Enterprise Technologies, Vol. 2, no. 10, 27-37 (2020). DOI: https://doi.org/10.15587/1729-4061.2020.200591

9. Teliura, N.O.: Ensuring of an ecological safety of eutrophic water bodies via the implementation of priority water disposal technologies in settlements. Wissenschaft für den modernen Menschen: innovative technik und technologie, informatik sicherheitssysteme, verkehrsentwicklung, architektur: monografische reihe «Europäische Wissenschaft». Karlsruhe, Germany: ScientificWorld-NetAkhatAV, Buch 4, Teil 4, 10-19 (2021).

10. Teliura, N.O.: Increasing of an ecological safety of eutrophic water bodies via the implementation of priority water disposal technologies in settlements : dys. ... kand. tekhn. nauk: 21.06.01. Kharkiv (2019) [in Ukrainian].

11. Kavanagh, Camino: New Tech, New Threats, and New Governance Challenges: An Opportunity to Craft / Carnegie Endowment for International Peace. https://carnegieendowment.org/files/WP_Camino_Kavanagh_ _New_Tech_New_Threats.pdf (2019).

Рецензент: д-р техн. наук, проф. О.В. Саввова, Харківський національний університет міського господарства імені О.М. Бекетова, Україна.

Автор: ТЕЛЮРА Наталя Олександрівна кандидат технічних наук, доиент, доиент кафедри Харківський національний університет міського господарства імені О.М. Бекетова

E-mail_nata.teliura@ukr.net

ID ORCID: https://orcid.org/0000-0003-0732-7789

\section{АКТУАЛЬНІ ПИТАННЯ ТЕХНОЛОГІЧНИХ ТА ОРГАНІЗАЦІЙНО-ЕКОНОМІЧНИХ ІНСТРУМЕНТІВ УПРАВЛІННЯ ПРИРОДОКОРИСТУВАННЯМ, ЕКОЛОГІЧНА ОЦІНКА ТА ПІДПРИЕМНИЦТВО}

Н.О. Телюра

Харківський національний університет міського господарства імені О.М. Бекетова, Україна

Одним з основних завдань екологічної галузі є інновації які стають на сьогодні запорукою технологічного прогресу. Технологічні та організаційно-економічні інструменти, особливо з точки зору природокористування, екологічної очінки та підприємництва, спрямовані головним чином на впровадження ефективних, дієвих заходів, спрямованих на подолання глибокої екологічної кризи та забезпечення умов сталого розвитку держави. Технологічний та організаційно-економічний механізми екологізації представляє собою сукупність організаційних форм та економічних важелів, взаємодія яких дозволяє забезпечувати здійснення процесу, щз ииклічно повторюється, спрямованого на підвищення економіко-екологічної ефективності суспільного виробництва і стимулювання проведення природоохоронних заходів. Зелене (еко-) підприємниитво є альтернативним баченням зростання та розвитку. Необхідим стає переосмислення теоретичних підходів та чіткого з'ясування сутності організаційно-економічного механізму стійкості функиіонування еко-підприємств для його ефективного формування та здійснення подальших наукових досліджень в иіій області. Очікується, щзо ичі прориви призведуть до значних трансформаційних змін у функиіонуванні суспільства. Ці досягнення обічяють значні сочіальні та економічні вигоди, підвищення ефективності та підвищення продуктивності в багатьох галузях. Інновації, включаючи технологічні та організаційно-економічні інструменти, зосереджені на зборі, обробці та аналізі величезних масивів даних, щзо надходять з інформаційних наук, матимуть наслідки для незліченних областей досліджень та розробок. Розроблений інновачійний методичний підхід визначення та обтрунтування пріоритетних управлінських технологічних та організаційно-економічних рімень за МАI, дозволяє задіяти експертів екологічного, містобудівного, соціального, економічного спрямування муніципальних органів управління конкретного населеного пункту, промислових, житлових та військових об'єктів, до обтрунтування рішень в управлінні екологічною безпекою населених пунктів, тощо. До переваг методичного підходу слід віднести -можливість ув'язати до єдиного алгоритму обтрунтування рішення даних, щзо різняться як за своїм змістом (екологічні, біологічні по вищим водним рослинам, містобудівні, соціальні та економічні), так $і$ за формою представлення (дані безпосередніх вимірів, статистичні та прогнозні оцінки) для розробки єдиної пропозииї щэодо застосування в практииі сучасного господарювання.

Ключові слова: технологічні та організаційно-економічні інструменти, трунтовий покрив, управління проектами та програмами, екологічна оцінка та підприємництво. 